\section{Role of PEPT2 in the Choroid Plexus Uptake of Glycylsarcosine and 5-Aminolevulinic Acid: Studies in Wild-Type and Null Mice}

\author{
Scott M. Ocheltree, ${ }^{1}$ Hong Shen, ${ }^{1}$ Yongjun Hu, ${ }^{1}$ \\ Jianming Xiang, ${ }^{2}$ Richard F. Keep, ${ }^{2}$ and \\ David E. Smith ${ }^{1,3}$
}

Received April 8, 2004; accepted May 16, 2004

Purpose. To determine the importance of PEPT2 in the uptake of glycylsarcosine (GlySar) and 5-aminolevulinic acid (5-ALA) in mouse choroid plexus whole tissue.

Methods. Uptake studies were performed in bicarbonate artificial cerebrospinal fluid buffer using choroid plexuses isolated from $\mathrm{PEPT}^{+/+}$and $\mathrm{PEPT}^{-/-}$mice. $\left[{ }^{14} \mathrm{C}\right]$ GlySar and $\left[{ }^{14} \mathrm{C}\right] 5$-ALA were studied as a function of temperature, concentration, potential inhibitors, and low sodium conditions.

Results. PEPT $2^{-/-}$mice exhibited a $90 \%$ reduction in GlySar uptake $(\mathrm{p}<0.001)$ and a $92 \%$ reduction in 5-ALA uptake $(\mathrm{p}<0.001)$ as compared to wild type animals. At $4^{\circ} \mathrm{C}$ (vs. $37^{\circ} \mathrm{C}$ ), GlySar uptake was reduced by $95 \%$ in $\mathrm{PEPT}_{2}^{+/+}$mice; no difference was observed in null animals. Unlabeled GlySar inhibited the uptake of $\left[{ }^{14} \mathrm{C}\right] \mathrm{GlySar}$ in PEPT2 $^{+/+}$mice $(\mathrm{p}<0.01)$; self-inhibition did not occur in PEPT2 $2^{-/-}$ mice. GlySar demonstrated saturable uptake in PEPT2 $2^{+/+}$mice $\left(\mathrm{V}_{\max }\right.$ $\left.=16.4 \mathrm{pmol} \mathrm{mg}^{-1} \mathrm{~min}^{-1}, \mathrm{~K}_{\mathrm{m}}=70 \mu \mathrm{M}, \mathrm{K}_{\mathrm{d}}=0.014 \mu \mathrm{mg}^{-1} \mathrm{~min}^{-1}\right)$, however, uptake was linear in PEPT2 ${ }^{-1-}$ mice $\left(\mathrm{K}_{\mathrm{d}}=0.023 \mu \mathrm{l} \mathrm{mg}^{-1}\right.$ $\left.\min ^{-1}\right)$. Low sodium buffer $(1 \mathrm{mM})$ resulted in $75 \%$ and $59 \%$ reductions, respectively, in GlySar $(\mathrm{p}<0.001)$ and 5-ALA $(\mathrm{p}<0.01)$ uptake in $\mathrm{PEPT}^{+/+}$mice; no differences were observed in PEPT2 ${ }^{-/-}$mice. Overall, about $90-95 \%$ of the choroid plexus uptake of GlySar and 5-ALA was mediated by PEPT2, with about $5-10 \%$ of the residual uptake occurring by nonspecific mechanisms.

Conclusions. The results demonstrate that PEPT2 is the only transporter responsible for the choroid plexus uptake of GlySar and 5-ALA. They also suggest a role for PEPT2 in the clearance of dipeptides and endogenous peptidomimetics from cerebrospinal fluid.

KEY WORDS: 5-ALA; choroid plexus; GlySar; knockout mouse; PEPT2.

\section{INTRODUCTION}

The choroid plexus is a highly vascularized single layer of cuboidal epithelium that lines the ventricles of the brain and produces $65-75 \%$ of cerebrospinal fluid (CSF) in humans (1). In addition, the choroid plexus functions as an important physiologic and pharmacologic barrier, commonly referred to as blood-CSF-barrier (BCSFB) (2). The BCSFB is created

\footnotetext{
${ }^{1}$ Department of Pharmaceutical Sciences, The University of Michigan, Ann Arbor, Michigan 48109, USA.

${ }^{2}$ Departments of Neurosurgery and Physiology, The University of Michigan, Ann Arbor, Michigan 48109, USA.

${ }^{3}$ To whom correspondence should be addressed. (e-mail: smithb@ umich.edu)

ABBREVIATIONS: aCSF, artificial cerebrospinal fluid; 5-ALA, 5-aminolevulinic acid; BCSFB, blood-cerebrospinal fluid barrier; CSF, cerebrospinal fluid; DMA, dimethylamiloride; GlySar, glycylsarcosine; PEPT, peptide transporter; PHT, peptide/histidine transporter.
}

through the formation of tight junctions between the choroidal epithelial cells and by detoxification systems, which may include membrane-bound efflux transporters. These transporters not only serve a critical role in protecting the brain from potentially toxic endo- and xenobiotics, but are also important in selectively regulating the distribution of many physiologically and pharmacologically important compounds between the blood and CSF.

PEPT2, one of four current members of the mammalian proton-coupled oligopeptide transporter family (i.e., PEPT1, PEPT2, PHT1, PHT2) (3), is an electrogenic, sodiumindependent transporter that translocates small peptides (i.e., sequence independent di-and tripeptides) along with protons across biologic membranes via an inwardly directed electrochemical gradient of protons. It was initially cloned from a human kidney cDNA library (4) and is characterized as a high affinity (i.e., $\mu \mathrm{M} \mathrm{K}_{\mathrm{m}}$ values), low capacity transporter (5). PEPT2 mRNA transcripts $(6,7)$, protein $(8,9)$ and functional activity (10-14), along with PHT1 mRNA transcripts (15) have been described in the choroid plexus. Functional and immunocytochemical data in primary cultures of rat choroid plexus epithelial cells have demonstrated that PEPT2 is expressed on the apical plasma membrane (i.e., CSF-facing) and functions to clear di- and tripeptides from CSF (9). The functional role of PHT1 still remains uncertain.

The recent generation of PEPT2 knockout mice by this laboratory (13) and by Rubio-Aliaga and coworkers (16) has provided a powerful tool to directly examine the physiologic and pharmacologic significance of PEPT2 in the transport of small peptides and peptidomimetics in multiple organ systems. Recent results have provided strong evidence that PEPT2 is the primary transporter for uptake of carnosine ( $\beta$-alanyl-L-histidine) and cefadroxil (aminocephalosporin) at the BCSFB $(12,14)$. However, in the cefadroxil study $(12)$, there was a secondary component mediated by an organic anion transporter, the relative importance of which varied with concentration. The possibility that multiple transporters may be involved in the transport of peptides and peptidomimetics emphasizes the importance of expanding our knowledge of the relative role PEPT2 in transport at the choroid plexus. Although there is evidence for the PEPT2-mediated uptake of glycylsarcosine (GlySar) and 5-aminolevulinic acid (5-ALA) into choroid plexus, sodium removal significantly reduces transport $(8,10)$. Considering that PEPT2 is a sodiumindependent transporter, this suggests the possibility of an unidentified second transporter for such compounds $(8,10)$. GlySar is a synthetic, hydrolysis- and peptidase-resistant dipeptide commonly used for peptide transport studies. 5-ALA is an endogenous peptidomimetic substrate for PEPT2 $(8,17,18)$. It is a precursor of porphyrins and heme, and has been used as a photosensitizer in photodynamic therapy for various tumors.

With this in mind, the objective of this study was to determine the importance of PEPT2 in the uptake of GlySar and 5-ALA by the choroid plexus. Studies were performed using whole-tissue choroid plexus preparations isolated from wild-type and PEPT2 null mice. Our findings conclusively demonstrate that PEPT2 has a critical role in the trafficking of small peptides and endogenous peptidomimetic compounds at the BCSFB. 


\section{MATERIALS AND METHODS}

All studies were carried out in accordance with the Guide for the Care and Use of Laboratory Animals as adopted and promulgated by the U.S. National Institutes of Health (NIH publication No. 85-23, revised in 1985).

\section{Materials}

$\left[{ }^{14} \mathrm{C}\right]$ GlySar $(106 \mathrm{mCi} / \mathrm{mmol})$ was supplied by Amersham Biosciences (Chicago, IL), $\left[{ }^{14} \mathrm{C}\right] 5$-ALA $(51.5 \mathrm{mCi} / \mathrm{mmol})$ by New England Nuclear Life Science Products (Boston, MA), and $\left[{ }^{3} \mathrm{H}\right]$ mannitol $(17 \mathrm{Ci} / \mathrm{mmol})$ by Perkin Elmer Life Sciences Inc. (Boston, MA). Nylon net filters $(100 \mu \mathrm{m})$ were obtained from Millipore Co. (Billerica, MA). Dimethylamiloride (DMA) and unlabeled GlySar were obtained from Sigma (St. Louis, MO), and hyamine hydroxide from ICN (Irvine, CA). All other chemicals were obtained from standard sources. PEPT2-transgenic mice were generated on a C57BL/6 mouse background and genotyped by RT-PCR, as described previously by Shen et al. (13).

\section{Transport Buffers}

Uptake experiments were performed in bicarbonate artificial CSF (aCSF) buffer ( $\mathrm{pH} 7.4$ ). aCSF buffer was continuously bubbled with $5 \% \mathrm{CO}_{2}, 95 \% \mathrm{O}_{2}$ and contained $127 \mathrm{mM}$ $\mathrm{NaCl}, 20 \mathrm{mM} \mathrm{NaHCO} 3,2.4 \mathrm{mM} \mathrm{KCl}, 0.5 \mathrm{mM} \mathrm{KH} \mathrm{PO}_{4}, 1.1$ $\mathrm{mM} \mathrm{CaCl} 2,0.85 \mathrm{mM} \mathrm{MgCl}_{2}, 0.5 \mathrm{mM} \mathrm{Na}_{2} \mathrm{SO}_{4}$, and $5.0 \mathrm{mM}$ glucose (pH 7.4). Low sodium (1 mM) aCSF buffer was prepared by substituting choline chloride for $\mathrm{NaCl}$ and choline bicarbonate for $\mathrm{NaHCO}_{3}$.

\section{GlySar and 5-ALA Uptake}

All uptake experiments were performed in parallel for $\mathrm{PEPT}^{+/+}$and $\mathrm{PEPT}^{-/-}$littermates (6-8 weeks old). Detailed methods for the surgical isolation of the choroid plexus are described in Keep and Xiang (19) for glutamine uptake. Briefly, the lateral and fourth ventricle choroid plexuses were isolated from anesthetized (pentobarbital; $65 \mathrm{mg} / \mathrm{kg}$ i.p.) mice, weighed and transferred to bicarbonate aCSF buffer at $37^{\circ} \mathrm{C}$. Each sample consisted of six pooled plexuses from two animals. A 5-min recovery period was allowed before the beginning of each experiment. After the recovery period, the plexuses were transferred to $0.95 \mathrm{ml}$ of transport buffer, with or without a potential inhibitor, for $0.5 \mathrm{~min}$. Uptake was initiated by addition of $0.05 \mathrm{ml}$ of buffer with approximately 0.2 $\mu \mathrm{Ci}$ of $\left[{ }^{14} \mathrm{C}\right]$ GlySar $(1.9 \mu \mathrm{M})$ or $\left[{ }^{14} \mathrm{C}\right] 5$-ALA $(5.0 \mu \mathrm{M})$ and 0.4 $\mu \mathrm{Ci}$ of $\left[{ }^{3} \mathrm{H}\right]$ mannitol (an extracellular marker). Unless otherwise stated, the uptake was terminated after 3 min for GlySar or $2 \mathrm{~min}$ for 5-ALA by transferring the plexuses to ice-cold buffer and filtering under reduced pressure. The uptake time for each compound was based on previous time course data obtained in rat choroid plexus whole tissue $(8,10)$. The filters $(100-\mu \mathrm{m})$ were washed three times with cold transport buffer. The filters and choroid plexuses were then soaked in $0.33 \mathrm{ml}$ of $1 \mathrm{M}$ hyamine hydroxide (a tissue solubilizer) for $30 \mathrm{~min}$ before the addition of Ecolite $(+)$ scintillation cocktail (ICN; Irvine, CA) and counting with a dual-channel liquid scintillation counter (Beckman LS 3801; Fullerton, CA).

The uptake of radiolabeled substrate into choroid plexus, in microliters per milligram of wet tissue weight, was calculated as (19):

$$
\text { Substrate Uptake }=\frac{(\mathrm{St}-\mathrm{Sf})-(\mathrm{Mt}-\mathrm{Mf}) \cdot \text { ratio }}{\text { Smedia }}
$$

where St is the total substrate concentration in the plexus plus filter, Sf is the filter binding of substrate, and Smedia is the substrate concentration in the external media. The $(\mathrm{Mt}-$ Mf) - ratio term is a correction for extracellular space, where $\mathrm{Mt}$ is the total mannitol concentration in the plexus plus filter and $\mathrm{Mf}$ is the filter binding of mannitol. Multiplying this difference by the ratio of $\left[{ }^{14} \mathrm{C}\right]$ to $\left[{ }^{3} \mathrm{H}\right]$ in the external medium provides an estimate of the extracellular content of each substrate. The unidirectional influx rate $(\mathrm{V})$ can then be calculated by multiplying substrate uptake by Smedia and dividing by the duration of the experiment.

\section{Data Analysis}

For kinetic studies, the concentration-dependent uptake of GlySar was best fit to a Michaelis-Menten relationship with a nonsaturable component:

$$
\mathrm{V}=\frac{\mathrm{V}_{\max } \cdot \mathrm{C}}{\mathrm{K}_{\mathrm{m}}+\mathrm{C}}+\mathrm{K}_{\mathrm{d}} \cdot \mathrm{C}
$$

where $\mathrm{V}_{\max }$ is the maximal rate of saturable uptake, $\mathrm{K}_{\mathrm{m}}$ is the Michaelis constant, $K_{d}$ is the rate constant for nonsaturable processes, and $\mathrm{C}$ is the substrate concentration.

To evaluate if more than one class of transporters was operational for GlySar uptake, a Woolf-AugustinssonHofstee transformation was performed on the saturable component of Eq. $2\left(\mathrm{v}^{\prime}=\mathrm{V}-\mathrm{K}_{\mathrm{d}} \mathrm{C}\right)$ such that:

$$
\mathrm{v}^{\prime}=\mathrm{V}_{\text {max }}-\mathrm{K}_{\mathrm{m}}\left(\mathrm{v}^{\prime} / \mathrm{C}\right)
$$

All data are reported as mean \pm SE. Statistical comparisons were performed with ANOVA (GraphPad Prism, v3.0; GraphPad Software, Inc., San Diego, CA) and post hoc pairwise comparisons made with Dunnett's test. A probability of $\mathrm{p} \leq 0.05$ was considered statistically significant. Linear and nonlinear regression analyses were performed with SigmaPlot 8.0 (SPSS Inc., Chicago, IL) and a weighting factor of unity. The quality of fit was determined by evaluating the coefficient of determination $\left(\mathrm{r}^{2}\right)$, the coefficient of variation $(\mathrm{CV} \%)$ of parameter estimates, and by visual inspection of the residuals.

\section{RESULTS}

\section{GlySar Uptake}

$\mathrm{PEPT}^{-/-}$mice exhibited a significantly reduced uptake rate of $1.9 \mu \mathrm{M}$ GlySar (i.e., 90.1\%) under physiologic conditions $\left(\mathrm{pH} 7.4,37^{\circ} \mathrm{C}\right)$, as compared to PEPT $2^{+/+}$mice $(\mathrm{p}<$ 0.001; Fig. 1). Temperature had a dramatic effect on GlySar in which uptake was reduced by $96 \%$ at $4^{\circ} \mathrm{C}$ (vs. $37^{\circ} \mathrm{C}$ ) in $\mathrm{PEPT}^{+/+}$mice. In contrast, no significant reduction was observed in PEPT2 null animals at the lower temperature. The uptake rate of $1.9 \mu \mathrm{M}\left[{ }^{14} \mathrm{C}\right] \mathrm{GlySar}\left(\mathrm{pH} 7.4,37^{\circ} \mathrm{C}\right)$ was subsequently examined in the presence of saturating concentrations of unlabeled substrate $(5 \mathrm{mM})$. It was found that in $\mathrm{PEPT}^{+/+}$mice, excess GlySar reduced the uptake of radiolabeled GlySar to values observed at $4^{\circ} \mathrm{C}$ for both genotypes, and to uptake rates observed at $37^{\circ} \mathrm{C}$ in $\mathrm{PEPT} 2^{-1-}$ mice in the 


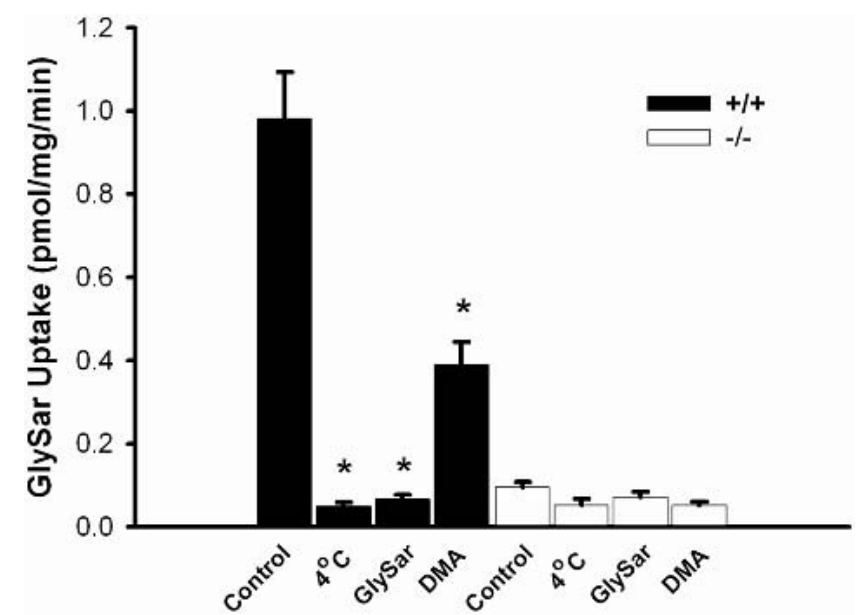

Fig. 1. Uptake rate of $\left[{ }^{14} \mathrm{C}\right] \mathrm{GlyS}$ ar $(1.9 \mu \mathrm{M}$ GlySar in external media) in $\mathrm{PEPT}^{+/+}$and $\mathrm{PEPT}^{-/-}$mice as a function of temperature and potential inhibitors. Studies were performed in bicarbonate aCSF buffer $\left(\mathrm{pH} 7.4 ; 37^{\circ} \mathrm{C}\right)$, unless otherwise noted. Data are expressed as mean \pm SE ( $n=4$ to 6$)$. Dimethylamiloride (DMA) was present at $100 \mu \mathrm{M}$ and unlabeled GlySar was present at $5 \mathrm{mM}$. *p $<0.01$ as compared to control values for each genotype.

absence of inhibitors. Self-inhibition of radiolabeled GlySar, on the other hand, was conspicuously absent in PEPT2 ${ }^{-/-}$ mice.

The concentration-dependent uptake of GlySar (1-1000 $\mu \mathrm{M})$ was investigated in both genotypes under physiologic conditions (Fig. 2A). PEPT2 ${ }^{+/+}$mice demonstrated saturable transport with a maximum velocity $\left(\mathrm{V}_{\text {max }}\right)$ of $16.4 \pm 0.9$ pmol $\mathrm{mg}^{-1} \mathrm{~min}^{-1}$, a Michaelis constant $\left(\mathrm{K}_{\mathrm{m}}\right)$ of $70 \pm 9 \mu \mathrm{M}$, and $\mathrm{a}$ nonsaturable rate constant $\left(\mathrm{K}_{\mathrm{d}}\right)$ of $0.014 \pm 0.001 \mu \mathrm{lmg}$ $\mathrm{min}^{-1}$. A Woolf-Augustinsson-Hofstee transformation of the saturable uptake component $\left(\mathrm{v}^{\prime}\right)$ in $\mathrm{PEPT}^{+/+}$mice demonstrates strong linear behavior (Fig. $2 \mathrm{~B} ; \mathrm{r}^{2}=0.984$ ), indicating the presence of one class of transporters. Under linear conditions, the carrier-mediated component accounted for $95 \%$ of transport, while the nonspecific uptake component comprised only $5 \%$ of the total uptake in $\mathrm{PEPT} 2^{+/+}$mice. In contrast, $\mathrm{PEPT}^{-/-}$mice exhibited a much less efficient transport $\left(\mathrm{K}_{\mathrm{d}}\right.$ only of $\left.0.023 \pm 0.001 \mu \mathrm{mg}^{-1} \mathrm{~min}^{-1}\right)$. These results suggested the lack of additional carriers for GlySar and further strengthened the argument that PEPT2 was the only transporter involved in GlySar uptake at the mouse choroid plexus. Based on the calculated $\mathrm{K}_{\mathrm{d}}$ in $\mathrm{PEPT}^{+/+}$mice, the nonsaturable uptake rate at $1.9 \mu \mathrm{M}$ was estimated to be 0.028 pmol $\mathrm{mg}^{-1} \mathrm{~min}^{-1}$, a value that compares very well to the uptake rate of $1.9 \mu \mathrm{M}$ GlySar in $\mathrm{PEPT}^{+/+}$mice observed at $4{ }^{\circ} \mathrm{C}$ (i.e., $0.033 \mathrm{pmol} \mathrm{mg}^{-1} \mathrm{~min}^{-1}$; Fig. 1). A complete summary of the kinetic data is provided in Table I.

Dimethylamiloride (DMA; $100 \mu \mathrm{M}$ ), an inhibitor of the $\mathrm{Na}^{+} / \mathrm{H}^{+}$exchanger $(20,21)$, significantly reduced the uptake rate of GlySar in PEPT2 $2^{+/+}$mice (i.e., $60.3 \%$ reduction; $\mathrm{p}<$ 0.01 ), suggesting that a $\mathrm{Na}^{+} / \mathrm{H}^{+}$exchange-generated $\mathrm{pH}$ gradient is important for uptake (Fig. 1). In contrast, DMA had no effect on the uptake rate of GlySar in PEPT2 $2^{-/-}$mice. Low sodium aCSF buffer $(1 \mathrm{mM})$ resulted in a $75 \%$ reduction in the uptake of $1.9 \mu \mathrm{M}$ GlySar in PEPT $2^{+/+}$mice $(\mathrm{p}<0.001$; Fig. 3 ), however, it did not alter the uptake rate of GlySar in $\mathrm{PEPT}^{-/-}$mice. Since a Na-dependent uptake was found only in the presence of PEPT2, the reduced uptake of GlySar
A

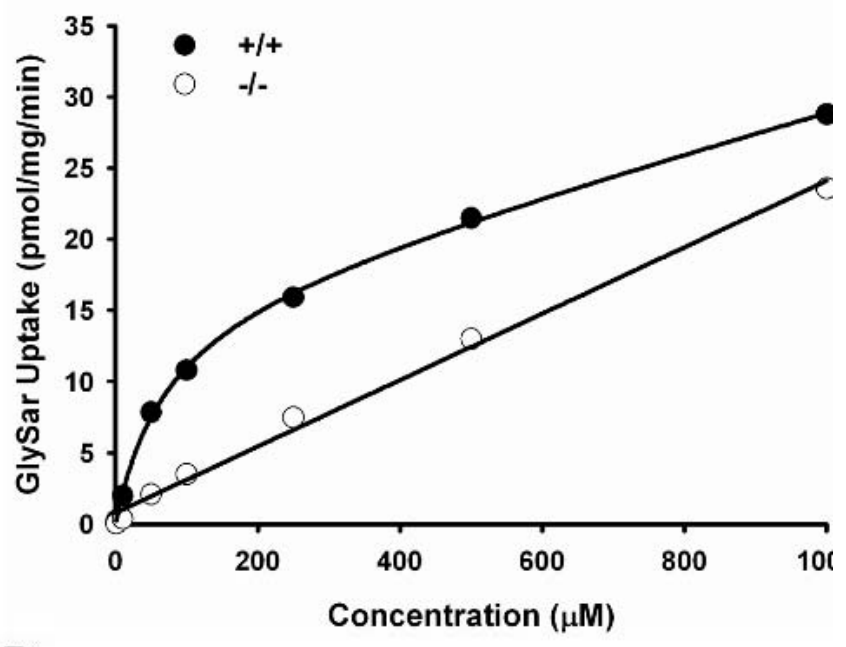

B

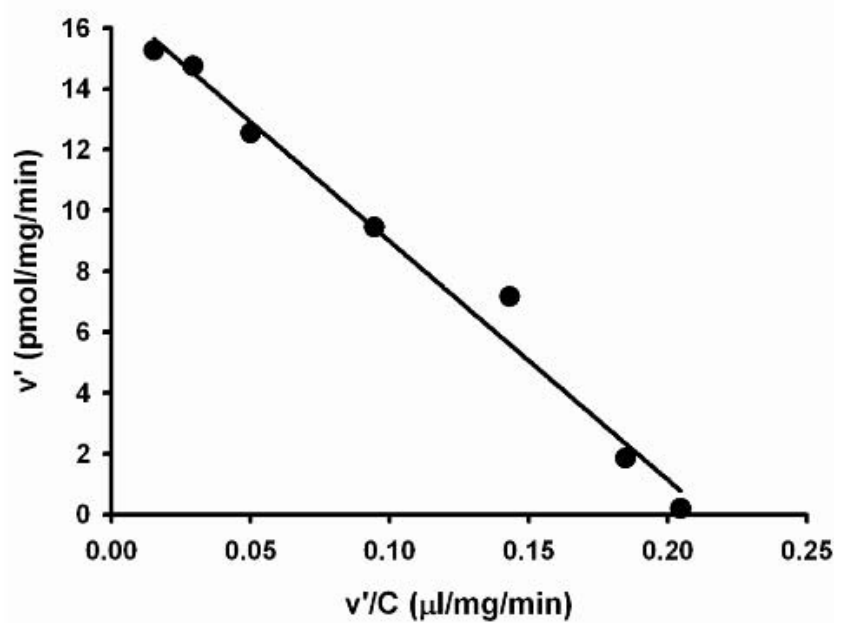

Fig. 2. (A) Concentration-dependent uptake rate of $\left[{ }^{14} \mathrm{C}\right]$ GlySar $(1-$ $1000 \mu \mathrm{M}$ total GlySar in external media) in $\mathrm{PEPT}^{+/+}(\mathbf{0})$ and $\mathrm{PEPT}^{-/-}$mice $(\mathrm{O})$. Predicted curves were generated using $\mathrm{V}_{\text {max }}, \mathrm{K}_{\mathrm{m}}$, and $\mathrm{K}_{\mathrm{d}}$ values reported in the text and Table I. Studies were performed in bicarbonate aCSF buffer $\left(\mathrm{pH} 7.4 ; 37^{\circ} \mathrm{C}\right)$. Data are expressed as the mean of two preparations, where each preparation consists of six pooled plexuses from two mice. (B) WoolfAugustinsson-Hofstee transformation of the saturable uptake component $\left(\mathrm{v}^{\prime}\right)$ in $\mathrm{PEPT}^{+/+}$mice $\left(\mathrm{r}^{2}=0.984\right)$.

Table I. GlySar Uptake Kinetics in Wild-Type and PEPT2 Null Animals

\begin{tabular}{lcc}
\hline \multicolumn{1}{c}{ Parameter* } & PEPT2 $^{+/+}$ & PEPT2 $^{-/-}$ \\
\hline $\mathrm{V}_{\max }\left(\mathrm{pmol} \mathrm{mg}^{-1} \mathrm{~min}^{-1}\right)$ & $16.4(0.9)$ & - \\
$\mathrm{K}_{\mathrm{m}}(\mu \mathrm{M})$ & $70(9)$ & - \\
$\mathrm{K}_{\mathrm{d}}\left(\mu \mathrm{l} \mathrm{m} \mathrm{mi}^{-1} \mathrm{~min}^{-1}\right)$ & $0.014(0.001)$ & $0.023(0.001)$ \\
$\mathrm{V}_{\max } / \mathrm{K}_{\mathrm{m}}\left(\mu \mathrm{mg}^{-1} \mathrm{~min}^{-1}\right)$ & 0.23 & - \\
$\mathrm{r}^{2}$ & 0.999 & 0.993 \\
\hline
\end{tabular}

* Parameter estimates $( \pm \mathrm{SE})$ were derived by nonlinear (or linear) regression models. $\mathrm{r}^{2}$ is the coefficient of determination. 




Fig. 3. Uptake rate of $\left[{ }^{14} \mathrm{C}\right]$ GlySar $(1.9 \mu \mathrm{M}$ GlySar in external media) in $\mathrm{PEPT}^{+/+}$and $\mathrm{PEPT}^{-1-}$ mice as a function of sodium. Studies were performed in bicarbonate aCSF buffer $\left(\mathrm{pH} 7.4 ; 37^{\circ} \mathrm{C}\right)$ under normal sodium $(+\mathrm{Na})$ and low sodium $(-\mathrm{Na})$ conditions. Data are expressed as mean $\pm \operatorname{SE}(n=3)$. ** $<0.001$ as compared to normal sodium buffer for each genotype.

probably reflects an indirect effect via inhibition of $\mathrm{Na}^{+} / \mathrm{H}^{+}$ exchange.

\section{5-ALA Uptake}

Under physiologic conditions (i.e., normal sodiumcontaining aCSF buffer, $37^{\circ} \mathrm{C}$ ), the influx rate of $5.0 \mu \mathrm{M}$ 5-ALA was reduced by $92.3 \%$ in PEPT2 null mice, as compared to wild-type controls (Fig. 4; $\mathrm{p}<0.001$ ). Low sodium aCSF buffer $(1 \mathrm{mM})$ resulted in a $59 \%$ reduction in the uptake of 5-ALA in PEPT $2^{+/+}$mice $(\mathrm{p}<0.01$; Fig. 3) but, as observed with GlySar, it did not significantly alter the uptake rate of 5-ALA in $\mathrm{PEPT}^{-/-}$mice.

\section{DISCUSSION}

Gene knockout is an elegant approach for obtaining new insights into the physiologic and pharmacologic significance of transport proteins that belong to multiple gene families.

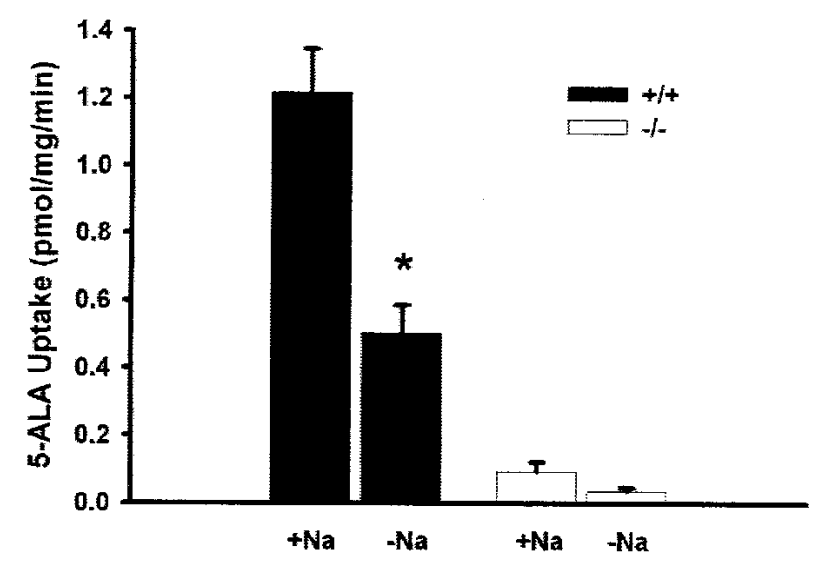

Fig. 4. Uptake rate of $\left[{ }^{14} \mathrm{C}\right] 5$-ALA $(5.0 \mu \mathrm{M}$ 5-ALA in external media) in $\mathrm{PEPT}^{+/+}$and PEPT2 $2^{-/-}$mice as a function of sodium. Studies

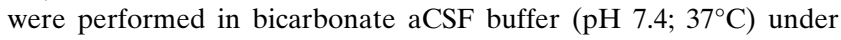
normal sodium $(+\mathrm{Na})$ and low sodium $(-\mathrm{Na})$ conditions. Data are expressed as mean \pm SE $(n=4)$. ${ }^{*} \mathrm{p}<0.01$ as compared to normal sodium buffer for each genotype.
Results from this approach are just beginning to emerge for the PEPT2-mediated transport of peptides/mimetics at the choroid plexus (12-14). This paper extends these findings and indicates that PEPT2 is the sole carrier for GlySar and 5-ALA transport in isolated choroid plexus.

PEPT2 transports a wide range of di- and tripeptides in the kidney and brain $(3,5,9-11,14,22)$. GlySar has often been used as a model substrate for peptide transport studies because it is hydrolysis and peptidase resistant. In our initial study describing the development of transgenic mice (13), a marked reduction in the choroid plexus uptake of GlySar was noted in the PEPT2 null animals. However, these experiments were limited by the use of nonphysiologic Tris-Mes buffer and conditions that were optimized for PEPT2 transport (i.e., at pH 6.5). Moreover, inhibition experiments as well as concentration- and temperature-dependent studies were not performed and, as a result, the authors could not exclude the possibility that other transporters were involved in GlySar uptake. The present study was performed using physiologic conditions (i.e., aCSF buffer, at pH 7.4), and demonstrated that the choroid plexus uptake rate for GlySar was substantially reduced $(\sim 90 \%)$ in PEPT2 null mice.

Analyses of the transport kinetics of GlySar in choroid plexus indicate that (under linear conditions) the active uptake mechanism accounts for $95 \%$ of total uptake in wild-type controls. The kinetic analyses also show that only one class of transporters mediate GlySar uptake in PEPT2 $2^{+/+}$mice, a finding that is consistent with the lack of saturability observed in $\mathrm{PEPT}^{-/-}$mice. The estimated transport parameters for PEPT2 in wild-type mice are also similar to findings in other experimental systems. The Michaelis constant for GlySar uptake in our system $\left(\mathrm{K}_{\mathrm{m}}=70 \mu \mathrm{M}\right)$ is comparable to values reported for the PEPT2-mediated uptake of GlySar in choroid plexus whole tissue from rat $\left(\mathrm{K}_{\mathrm{m}}=129 \mu \mathrm{M}\right)(10)$ and in neonatal rat choroid plexus cells in primary culture $\left(\mathrm{K}_{\mathrm{m}}=60\right.$ $\mu \mathrm{M})$ (9). Teuscher et al. (14) also found that PEPT2 is responsible for approximately $95 \%$ of the choroid plexus uptake of the neuropeptide, carnosine ( $\beta$-alanyl-L-histidine). In combination with the current results for GlySar, PEPT2 appears to be the primary, if not sole, transporter responsible for dipeptide clearance from CSF at the choroid plexus.

In addition to small peptides, PEPT2 transports peptidomimetics. In particular, PEPT2 has been shown to transport a number of pharmacologically active agents including $\beta$-lactam antibiotics (e.g., $\alpha$-amino containing penicillins and cephalosporins), angiotensin converting enzyme inhibitors and nucleoside analog prodrugs (23), as well as 5-ALA $(8,17,18)$. Experiments on whole-tissue choroid plexus preparations isolated from wild-type and PEPT2 null mice demonstrated that (under linear conditions) the uptake of cefadroxil is primarily mediated by PEPT2 ( $80-85 \%)$, and to a minor extent by an organic anion transporter(s) (10-15\%) and nonspecific, temperature-independent mechanisms (5\%) (12). The current study examined the endogenous peptidomimetic 5-ALA. The choroid plexus uptake rate of 5-ALA was substantially reduced $(\sim 92 \%)$ in PEPT2 null mice under physiologic conditions. Previous kinetic data in rat choroid plexus whole tissue estimated a $K_{m}$ for 5-ALA of $260 \mu \mathrm{M}(8)$. Thus, the 5-ALA concentration used in these studies (i.e., $5 \mu \mathrm{M}$ ) was well below the level at which saturation might occur. Given that physiologic concentrations of 5-ALA in humans are $\sim 92 \mathrm{nM}$ in plasma and $19 \mathrm{nM}$ in CSF (24), the high-affinity 
transport kinetics of PEPT2 appears to be well suited for the efficient removal of 5-ALA (as well as small peptides) from the CSF. In combination with the findings of Ocheltree et al. (12), these results suggest that PEPT2 plays an important role in the trafficking of endogenous and exogenous peptidomimetics between CSF and blood.

Previous studies in rat choroid plexus whole tissue $(8,10)$ have suggested the presence of both sodium-dependent and sodium-independent uptake mechanisms for GlySar and 5-ALA. However, in these studies it was difficult to ascertain whether or not sodium removal reduced PEPT2 transport activity via an indirect effect on $\mathrm{Na}^{+} / \mathrm{H}^{+}$exchange. In the current study, sodium removal and inhibition of the $\mathrm{Na}^{+} / \mathrm{H}^{+}$ exchanger (via DMA) had profound effects on peptide/ mimetic uptake. For example, the choroid plexus uptake of GlySar and 5-ALA was reduced by $75 \%$ and $59 \%$, respectively, in $\mathrm{PEPT}^{+/+}$mice, but was unaffected in $\mathrm{PEPT}^{-/-}$ mice upon removal of sodium from aCSF buffer. Moreover, uptake was almost completely abolished in the null animals, as compared to wild type controls. Likewise, inhibition studies with DMA showed a $60 \%$ reduction in the choroid plexus uptake of GlySar in PEPT2 ${ }^{+/+}$mice, with no effect in null animals. These results suggest that the driving force for peptide/mimetic uptake in choroid plexus occurs via an extracellular to intracellular electrochemical proton gradient generated by a $\mathrm{Na}^{+} / \mathrm{H}^{+}$exchange mechanism. Further, the protonmotive force is needed for maximal PEPT2-mediated transport. Finally, it should be appreciated that GlySar and 5-ALA demonstrated a very similar pattern of choroid plexus uptake, under low sodium conditions, as previously reported for carnosine (14). These studies with GlySar, 5-ALA and carnosine are reinforcing and argue against residual sodiumdependent mechanisms being present for their uptake in choroid plexus.

Although the peptide/histidine transporters PHT1 (15) and PHT2 (25) have been cloned from brain, and PHT1 transcripts have been found in choroid plexus, several factors argue against these transporters being involved in GlySar or 5-ALA uptake. In our studies with PEPT2 null mice, there was no difference in radiolabeled GlySar uptake when presented with DMA, excess unlabeled dipeptide, low sodium buffer or reduced temperature $\left(4^{\circ} \mathrm{C}\right)$. These findings lend further support to previous observations in which saturating concentrations of L-histidine could not inhibit the uptake of $\left[{ }^{14} \mathrm{C}\right]$ GlySar in rat choroid plexus epithelial cells in primary culture (9) or in rat choroid plexus whole tissue (10). Despite the uncertain function of PHT1 and PHT2 in the body, recent data have suggested an intracellular localization $(25,26)$, potentially serving a role in the intracellular trafficking of small peptides. Preliminary studies using semi-quantitative PCR (i.e., PHT1/GAPDH) also suggested that PHT1 levels were not different in the choroid plexuses of wild type versus null animals (unpublished observation).

In conclusion, our studies have characterized the functional significance of PEPT2 in the transport of GlySar and 5-ALA at the BCSFB. These findings conclusively demonstrate that PEPT2 is the sole carrier for GlySar and 5-ALA transport in the choroid plexus. Only a small percentage (i.e., $5-10 \%$ ) of the total uptake was governed by nonspecific, temperature-independent processes. Moreover, the data suggest a role for PEPT2 in the clearance of small peptides and endogenous peptidomimetic substrates from CSF. Future stud- ies will be directed at the in vivo pharmacokinetics and tissue distribution of peptides/mimetics in wild type and PEPT2 knockout mice, in an attempt to determine the role and importance of PEPT2 on a multi-organ level.

\section{ACKNOWLEDGMENTS}

This work was supported in part by Grants R01GM035498 (D.E.S.), R01NS034709 and P01HL018575 (R.F.K.). Scott M. Ocheltree was supported by an AFPE PreDoctoral Fellowship and the Pharmacological Sciences Training Program of the National Institutes of Health (GM07767).

\section{REFERENCES}

1. E. M. Wright. Transport processes in the formation of the cerebrospinal fluid. Rev. Physiol. Biochem. Pharmacol. 83:3-34 (1978).

2. M. Bradbury. The Concept of a Blood-Brain Barrier, John Wiley \& Sons, New York, 1979, pp. 38-60.

3. D. Herrera-Ruiz and G. T. Knipp. Current perspectives on established and putative mammalian oligopeptide transporters. $J$. Pharm. Sci. 92:691-714 (2002).

4. W. Liu, R. Liang, S. Ramamoorthy, Y.-J. Fei, M. E. Ganapathy, M. A. Hediger, V. Ganapathy, and F. H. Leibach. Molecular cloning of PEPT2, a new member of the $\mathrm{H}^{+}$/peptide cotransporter family, from human kidney. Biochim. Biophys. Acta 1235: 461-466 (1995).

5. H. Daniel and M. Herget. Cellular and molecular mechanisms of renal peptide transport. Am. J. Physiol. 273:F1-F8 (1997).

6. U. V. Berger and M. A. Hediger. Distribution of peptide transporter PEPT2 mRNA in the rat nervous system. Anat. Embryol. 199:439-449 (1999).

7. S. Choudhuri, N. J. Cherrington, N. Li, and C. D. Klaassen. Constitutive expression of various xenobiotics and endobiotic transporter mRNAs in the choroid plexus of rats. Drug Metab. Dispos. 31:1337-1345 (2003).

8. A. Novotny, J. Xiang, W. Stummer, N. S. Teuscher, D. E. Smith, and R. F. Keep. Mechanisms of 5-aminolevulinic acid uptake at the choroid plexus. J. Neurochem. 75:321-328 (2000).

9. C. Shu, H. Shen, N. S. Teuscher, P. J. Lorenzi, R. F. Keep, and D. E. Smith. Role of PEPT2 in peptide/mimetic trafficking at the blood-cerebrospinal fluid barrier: Studies in rat choroid plexus epithelial cells in primary culture. J. Pharmacol. Exp. Ther. 301: 820-829 (2002).

10. N. S. Teuscher, A. Novotny, R. F. Keep, and D. E. Smith. Functional evidence for the presence of PEPT2 in rat choroid plexus: Studies with glycylsarcosine. J. Pharmacol. Exp. Ther. 294:494499 (2000).

11. N. S. Teuscher, R. F. Keep, and D. E. Smith. PEPT2-mediated uptake of neuropeptides in rat choroid plexus. Pharm. Res. 18: 807-813 (2001).

12. S. M. Ocheltree, H. Shen, Y. Hu, J. Xiang, R. F. Keep, and D. E. Smith. Mechanisms of cefadroxil uptake in the choroid plexus: Studies in wild-type and PEPT2 knockout mice. J. Pharm. Exp. Ther. 308:462-467 (2004).

13. H. Shen, D. E. Smith, R. F. Keep, J. Xiang, and F. C. Brosius III. Targeted disruption of the PEPT2 gene markedly reduces dipeptide uptake in choroid plexus. J. Biol. Chem. 278:4786-4791 (2003).

14. N. S. Teuscher, H. Shen, C. Shu, J. Xiang, R. F. Keep, and D. E. Smith. Carnosine uptake in rat choroid plexus primary cell cultures and choroid plexus whole tissue from PEPT2 null mice. $J$. Neurochem. 89:375-382 (2004).

15. T. Yamashita, S. Shimada, W. Guo, K. Sato, E. Kohmura, T. Hayakawa, T. Takagi, and M. Tohyama. Cloning and functional expression of a brain peptide/histidine transporter. J. Biol. Chem. 272:10205-10211 (1997).

16. I. Rubio-Aliaga, I. Frey, M. Boll, D. Groneberg, H. M. Eichinger, R. Balling, and H. Daniel. Targeted disruption of the peptide transporter Pept2 gene in mice defined its physiological role in the kidney. Mol. Cell. Biol. 23:3247-3252 (2003).

17. F. Döring, J. Walter, J. Will, M. Föcking, M. Boll, S. Amasheh, 
W. Clauss, and H. Daniel. Delta-aminolevulinic acid transport by intestinal and renal peptide transporters and its physiological and clinical implications. J. Clin. Invest. 101:2761-2767 (1998).

18. S. R. Ennis, A. Novotny, J. Xiang, P. Shakui, T. Masada, W. Stummer, D. E. Smith, and R. F. Keep. Transport of 5-aminolevulinic acid between blood and brain. Brain Res. 959:226-234 (2003).

19. R. F. Keep and J. Xiang. N-system amino acid transport at the blood-CSF-barrier. J. Neurochem. 65:2571-2576 (1995).

20. J. Arakawa and A. Hara. Effect of 5-(N,N-Dimethyl)-amiloride, a specific inhibitor of $\mathrm{Na}(+) / \mathrm{H}(+)$ exchanger, on the palmitoylL-carnitine-induced mechanical and metabolic derangements in the isolated perfused rat heart. Pharmacol. 59:239-248 (1999).

21. L. Mirossay, A. Mirossay, E. Kocisova, I. Radvakova, P. Miskovsky, and J. Mojzis. Hypericin-induced phototoxicity of human leukemic cell line HL-60 is potentiated by omeperazole, an inhibitor of $\mathrm{H}^{+} \mathrm{K}^{+}$-ATPase and $5^{\prime}$-(N,N-dimethyl)-amiloride, an inhibitor of $\mathrm{Na}^{+} / \mathrm{H}^{+}$exchanger. Physiol. Res. 48:135-141 (1999).
22. H. Daniel. Function and molecular structure of brush border membrane peptide/ $\mathrm{H}^{+}$symporters. J. Membr. Biol. 154:197-203 (1996).

23. I. Rubio-Aliaga and H. Daniel. Mammalian peptide transporters as targets for drug delivery. Trends Pharmacol. Sci. 23:434-440 (2002).

24. A. Gorchein and R. Webber. $\delta$-Aminolevulinic acid in plasma, cerebrospinal fluid, saliva and erythrocytes: Studies in normal, uraemic and porphyric subjects. Clin. Sci. 72:103-112 (1987).

25. K. Sakata, T. Yamashita, M. Maeda, Y. Moriyama, S. Shimada, and M. Tohyama. Cloning of a lymphatic peptide/histidine transporter. J. Biochem. 356:53-60 (2001).

26. S. M. Ocheltree, R. F. Keep, H. Shen, D. Yang, B. A. Hughes, and D. E. Smith. Preliminary investigation into the expression of proton-coupled oligopeptide transporters in neural retina and retinal pigment epithelium (RPE): Lack of functional activity in RPE plasma membranes. Pharm. Res. 20:1364-1372 (2003). 